Article

\title{
Mitigating the Drying Shrinkage and Autogenous Shrinkage of Alkali-Activated Slag by $\mathrm{NaAlO}_{2}$
}

\author{
Bin Chen, Jun Wang * and Jinyou Zhao * \\ College of Civil Engineering, Northeast Forestry University, Harbin 150040, China; chenbin@nefu.edu.cn \\ * Correspondence: jun.w.619@nefu.edu.cn (J.W.); jinyou2000@nefu.edu.cn (J.Z.)
}

Received: 2 June 2020; Accepted: 4 August 2020; Published: 8 August 2020

\begin{abstract}
The shrinkage of alkali-activated slag (AAS) is obviously higher than ordinary Portland cement, which limited its application in engineering. In this study, the effects of $\mathrm{NaAlO}_{2}$ in mitigating drying shrinkage and autogenous shrinkage of AAS were studied. To further understand the shrinkage mechanism, the hydration products and microstructures were studied by X-ray diffraction, scanning electron microscopy and nitrogen adsorption approaches. As the partial substitution rate of $\mathrm{NaAlO}_{2}$ for $\mathrm{Na}_{2} \mathrm{SiO}_{3}$ increased, the drying shrinkage and autogenous shrinkage reduced significantly. The addition of $\mathrm{NaAlO}_{2}$ could slow down the rate of hydration reaction and reduce the porosity, change the pore diameter and the composition of generated paste and cause more hydrotalcite and tetranatrolite generated-which contributed to reduced shrinkage. Additionally, raising the $\mathrm{Na}_{2} \mathrm{O}$ content rate caused obvious differences in drying shrinkage and autogenous shrinkage. As the $\mathrm{Na}_{2} \mathrm{O}$ content elevated, the drying shrinkage decreased and autogenous shrinkage increased. A high $\mathrm{Na}_{2} \mathrm{O}$ content would cause complete hydration reactions and provoke high autogenous shrinkage. However, incomplete hydration reactions left more water in the paste, and the evaporated water dramatically influenced drying shrinkage. The results indicate that addition of $\mathrm{NaAlO}_{2}$ could greatly mitigate the drying shrinkage and autogenous shrinkage of AAS.
\end{abstract}

Keywords: alkali-activated slag; drying shrinkage; autogenous shrinkage; mitigation

\section{Introduction}

Alkali-activated slag (AAS)-replaced ordinary Portland cement as a new binding material could be considered as possibility [1]. Realized by compounded blast furnace slag and alkaline activator was obtained the binding materials which is similar to cement. AAS could effectively reduce carbon dioxide emissions and energy consumption, while also effectively used industrial solid waste [2,3]. The AAS had good performance in early compressive strength, high temperature resistance and chemical corrosion resistance [4,5]. However, unsolved problems were existed, such as higher drying shrinkage and autogenous shrinkage [6,7].

Previous research has demonstrated that the shrinkage rate of AAS was significantly higher than that of ordinary Portland cement. The study by Lee et al. [8] provided that the AAS autogenous shrinkage and drying shrinkage at $28 \mathrm{~d}$ was about four and six times to that of ordinary Portland cement, respectively. Atiş et al. [9] reported that the AAS mortar drying shrinkage prepared with $\mathrm{Na}_{2} \mathrm{SiO}_{3}$ as an alkaline activator was three to six times to that of ordinary Portland cement mortar. Drying shrinkage of cementitious materials has already been confirmed that mainly due to the capillary stress, disjoining pressure and surface tension. Cartwright et al. [10] believed that the capillary stress was caused by the smaller pore diameter, which led to the AAS shrinkage. In addition, the C-A-S-H in the AAS hydration product was considered to be the main reason for the large shrinkage. The alkali metal cations in the reaction solution entered the $\mathrm{C}-\mathrm{A}-\mathrm{S}-\mathrm{H}$ gel, changed structures and led to collapse and redistributed upon drying [11,12]. 
High drying shrinkage and high autogenous shrinkage deformation could seriously influence the properties and durability of AAS, which limited the usage and promotion of AAS. Therefore, how to effectively mitigate the drying shrinkage and autogenous shrinkage of AAS became an important issue that must be solved urgently. Previous studies have found that the pore structure could mitigate shrinkage by adding different admixtures [13-15]. The main solutions to effectively mitigate the shrinkage of AAS were to reduce porosity, slow down hydration reaction rates or increase the stiffness of the microstructure. Abdel-Gawwad [16] demonstrated that the addition of $\mathrm{Al}_{2} \mathrm{O}_{3}$ in AAS produced a hydrotalcite structure with micro-swelling properties, which could effectively mitigate shrinkage. By changing the dose of $\mathrm{Al}^{3+}$ in the reaction solution, he could influence the hydration reaction rate. Haha [17] and Sakulich et al. [18] suggested that the addition of $\mathrm{Al}_{2} \mathrm{O}_{3}$ slowed down the hydration reaction rate- and the formation of hydrotalcite structure could effectively mitigate AAS shrinkage. According to extensive reports, the amount of $\mathrm{Al}^{3+}$ in the reaction solution can change the hydration reaction rate, while also significantly changing the microstructure. Therefore, this research proposes to use $\mathrm{NaAlO}_{2}$ partially substituted $\mathrm{Na}_{2} \mathrm{SiO}_{3}$ as a composite alkaline activator. The partial substitution of $\mathrm{NaAlO}_{2}$ for $\mathrm{Na}_{2} \mathrm{SiO}_{3}$ could provide $\mathrm{Al}^{3+}$ to the reaction solution; $\mathrm{Al}^{3+}$ was chosen as it has the ability to delay the hydration reaction rate and change the microstructure, which are beneficial for mitigating the AAS shrinkage. At the same time, $\mathrm{NaAlO}_{2}$ could provide the $\mathrm{OH}^{-}$, which was the required by the hydration reaction power and crucial for the AAS properties development. Moreover, considering the cumbersome procedures during the preparation of the liquid alkaline activator, it was proposed to use solid $\mathrm{NaAlO}_{2}$ and $\mathrm{Na}_{2} \mathrm{SiO}_{3}$ as composite solid alkaline activator, which would effectively improve efficiency and alleviate the alkali corrosion during the preparation and curing process. In short, the study of $\mathrm{NaAlO}_{2}$ partially substituted $\mathrm{Na}_{2} \mathrm{SiO}_{3}$ as a composite alkaline activator to prepare AAS could be a good idea to mitigate drying shrinkage and self-shrinkage. The study of hydration mechanism of mitigated shrinkage would be extremely important for the preparation of excellent AAS.

This study was aimed to study the effects of mitigating shrinkage by $\mathrm{NaAlO}_{2}$. In this study, we studied the effects of four different $\mathrm{NaAlO}_{2}$ substitution rates (for $20 \%, 40 \%, 60 \%$ and $80 \%$ ) and five different $\mathrm{Na}_{2} \mathrm{O}$ contents (for $3 \%, 5 \%, 7 \%, 9 \%$ and $11 \%$, which substitution rate fixed $20 \%$ ) of drying shrinkage and autogenous shrinkage. Furthermore, the hydration products, microstructures and pore structure were analyzed by $X$-ray diffraction (XRD), scanning electron microscopy (SEM) and nitrogen adsorption approach (Brunauer-Emmett-Teller theory), in order to understand the mechanism of hydration of mitigated shrinkage.

\section{Materials and Methods}

\subsection{Raw Material and Mixture Ratio}

Blast furnace slag with specific surface of $435 \mathrm{~m}^{2} / \mathrm{kg}$ was obtained from Minmetals Yingkou Medium Plate (Yingkou, China). According to the GB/T 18046-2017 [19], the slag was classified as S95. The chemical components are shown in Table $1 . \mathrm{NaAlO}_{2}$ (analytical pure) was provided by Dalu Chemical Reagent Factory (Tianjin, China). $\mathrm{Na}_{2} \mathrm{SiO}_{3}\left(\mathrm{Na}_{2} \mathrm{SiO}_{3} \cdot 9 \mathrm{H}_{2} \mathrm{O}\right.$, ratio of $\mathrm{Na}_{2} \mathrm{O}$ to $\mathrm{SiO}_{2}$ content was $1.03 \pm 0.03$ ) was provided by Xilong Scientific Chemical Reagent Factory (Shantou, China).

Table 1. Chemical components of blast furnace slag (\%).

\begin{tabular}{ccccccccc}
\hline Oxide & $\mathrm{CaO}$ & $\mathrm{SiO}_{2}$ & $\mathbf{M g O}$ & $\mathrm{Al}_{2} \mathbf{O}_{3}$ & $\mathrm{MnO}$ & $\mathrm{TiO}_{2}$ & $\mathrm{~S}$ & $\mathrm{FeO}$ \\
\hline Percentage/\% & 40.91 & 32.82 & 7.87 & 14.93 & 0.48 & 0.92 & 0.91 & 1.16 \\
\hline
\end{tabular}

Four different $\mathrm{NaAlO}_{2}$ substitution rates (for $20 \%, 40 \%, 60 \%$ and $80 \%$ ), five different $\mathrm{Na}_{2} \mathrm{O}$ contents (for 3\%, 5\%,7\%, $9 \%$ and $11 \%$, which substitution rate fixed 20\%) and a non-substituted control group were tested. The prepared mix proportions of AAS are shown in Table 2. For example, the code "NA0.2NS0.8-5" represents the alkaline activator with $\mathrm{NaAlO}_{2}$ substitution rates of $20 \%$ and $\mathrm{Na}_{2} \mathrm{SiO}_{3}$ 
content of $80 \%$ and $\mathrm{Na}_{2} \mathrm{O}$ contents $5 \%$. In order to reduce the influence of dosage to the test error, the slag was fixed to $2000 \mathrm{~g}$ and the water-slag ratio was kept constant at 0.35 .

Table 2. Mix proportions the prepared alkali-activated slag (AAS).

\begin{tabular}{ccccccc}
\hline Code & $\begin{array}{c}\mathbf{N a A l O}_{2} \text { Substitution } \\
\text { Rate (\%) }\end{array}$ & $\begin{array}{c}\mathbf{N a}_{2} \mathbf{O} \\
\text { Content (\%) }\end{array}$ & Slag (g) & $\mathbf{N a A l O}_{2}(\mathbf{g})$ & $\mathbf{N a}_{2} \mathbf{S i O}_{3}(\mathbf{g})$ & $\mathbf{H}_{\mathbf{2}} \mathbf{O}(\mathbf{g})$ \\
\hline NS1.0-5 & 0 & 5 & 2000 & 0.0 & 458.7 & 700 \\
NA0.2NS0.8-5 & 20 & 5 & 2000 & 52.9 & 366.9 & 700 \\
NA0.4NS0.6-5 & 40 & 5 & 2000 & 105.9 & 275.2 & 700 \\
NA0.6NS0.4-5 & 60 & 5 & 2000 & 158.7 & 183.5 & 700 \\
NA0.8NS0.2-5 & 80 & 5 & 2000 & 211.6 & 91.7 & 700 \\
NA0.2NS0.8-3 & 20 & 3 & 2000 & 31.7 & 220.1 & 700 \\
NA0.2NS0.8-7 & 20 & 7 & 2000 & 74.1 & 513.7 & 700 \\
NA0.2NS0.8-9 & 20 & 9 & 2000 & 95.2 & 660.5 & 700 \\
NA0.2NS0.8-11 & 20 & 11 & 2000 & 116.4 & 807.3 & 700 \\
\hline
\end{tabular}

\subsection{Test Methods}

\subsubsection{Drying Shrinkage}

The drying shrinkage test was on the basis of JC/T 603-2004 [20]. All prepared paste were poured into prismatic molds ( $\mathrm{h}=25 \mathrm{~mm}, \mathrm{w}=25 \mathrm{~mm}, 1=280 \mathrm{~mm}$ ). The sample was cured and measured in the curing room $\left(20 \pm 2{ }^{\circ} \mathrm{C}\right.$ and $\left.\mathrm{RH}>50 \%\right)$. The test start time was recorded from demolding done and the measurement accuracy was $0.001 \mathrm{~mm}$. The drying shrinkage was calculated according to Equation (1). Three samples were prepared for each code and the drying shrinkage was the mean value of three samples and recorded once per day until $28 \mathrm{~d}$.

$$
S_{n}=\frac{\left(L_{0}-L_{n}\right) \times 100}{280}
$$

$S_{n}$ was the drying shrinkage rate of the test at the age of $n \mathrm{~d}$ and the unit was $\% . L_{0}$ was the initial reading and the unit was mm. $L_{n}$ was the measurement of the test at the age of $n \mathrm{~d}$ and the unit was $\mathrm{mm}$. The effective length of the fixed value and the unit was $280 \mathrm{~mm}$.

\subsubsection{Autogenous Shrinkage}

An autogenous shrinkage test was under the standard ASTM C1697-09 [21]. This solution could effectively avoid moisture loss and minimize the constraints on volume changes. All prepared pastes were poured into a corrugated tube of $420 \mathrm{~mm}(\varnothing 28.5 \mathrm{~mm})$. The loaded samples were placed horizontally on a corrugated plastic board to avoid length changes and damage. The samples were cured and measured in the curing room $\left(20 \pm 2{ }^{\circ} \mathrm{C}\right.$ and $\left.\mathrm{RH}>50 \%\right)$. The start time of the test was recorded from the time of adding water to mix. The measurement accuracy was $0.001 \mathrm{~mm}$. The autogenous shrinkage was calculated according to Equation (2). Three samples were prepared for each code, and the drying shrinkage was the mean value of three samples and recorded once per day until $28 \mathrm{~d}$.

$$
\mu_{n}=\frac{\left(L_{n}-L_{0}\right) \times 10^{6}}{L_{0}},
$$

$\mu_{n}$ was the autogenous shrinkage rate of the test at the age of $n \mathrm{~d}$, and the unit was $\mu \varepsilon . L_{n}$ was the measurement of the test at the age of $n \mathrm{~d}$, and the unit was $\mathrm{mm}$. $L_{0}$ was the initial reading and the unit was mm.

\subsubsection{Instrumental Techniques}

In order to better understand the shrinkage performance of AAS with different mix ratios, scanning electron microscopy (SEM, JEOL-6360LV, Tokyo, Japan), X-ray diffraction (XRD, Empyrean-X, 
Amsterdam, The Netherlands) and Brunauer-Emmett-Teller (BET, Micromeritics ASAP 2020 instrument, Pullman, WA, USA) were used to analyze microstructures, hydration products and pore structures. The specimens from the crushed samples were poured into alcohol for $24 \mathrm{~h}$ to discontinue hydration. The specimens were removed from the alcohol and dried in a $60-^{\circ} \mathrm{C}$ oven for use before testing.

\section{Results and Discussion}

\subsection{Drying Shrinkage}

Figure 1 plots the effects of different $\mathrm{NaAlO}_{2}$ substitution rates on drying shrinkage. Drying shrinkage mainly occurred in the first $7 \mathrm{~d}$ and tended to increase steadily and slowly after $7 \mathrm{~d}$. At $7 \mathrm{~d}$, the drying shrinkage of the $\mathrm{NaAlO}_{2}$ substitution rate of $20 \%, 40 \%, 60 \%$ and $80 \%$ was $93 \%, 84 \%, 64 \%$ and $54 \%$ of control group (NS 1.0-5), respectively. The substitution of $\mathrm{NaAlO}_{2}$ for $\mathrm{Na}_{2} \mathrm{SiO}_{3}$ had a significant effect on mitigate shrinkage. Substitution rate of $\mathrm{NaAlO}_{2}$ has a significantly negative correlation with drying shrinkage. The main reason was that the rate of drying shrinkage was clearly related to the hydration reaction degree of the paste [22]. $\mathrm{Na}_{2} \mathrm{SiO}_{3}$ had stronger alkali activating ability. Neto et al. [23] noted that more $\mathrm{Na}_{2} \mathrm{SiO}_{3}$ content in the alkaline activator caused clear high drying shrinkage. Meanwhile, Ben et al. [17] reported that more soluble Al in the paste could delay the alkali-activated hydration reaction, which could contribute to mitigate drying shrinkage.

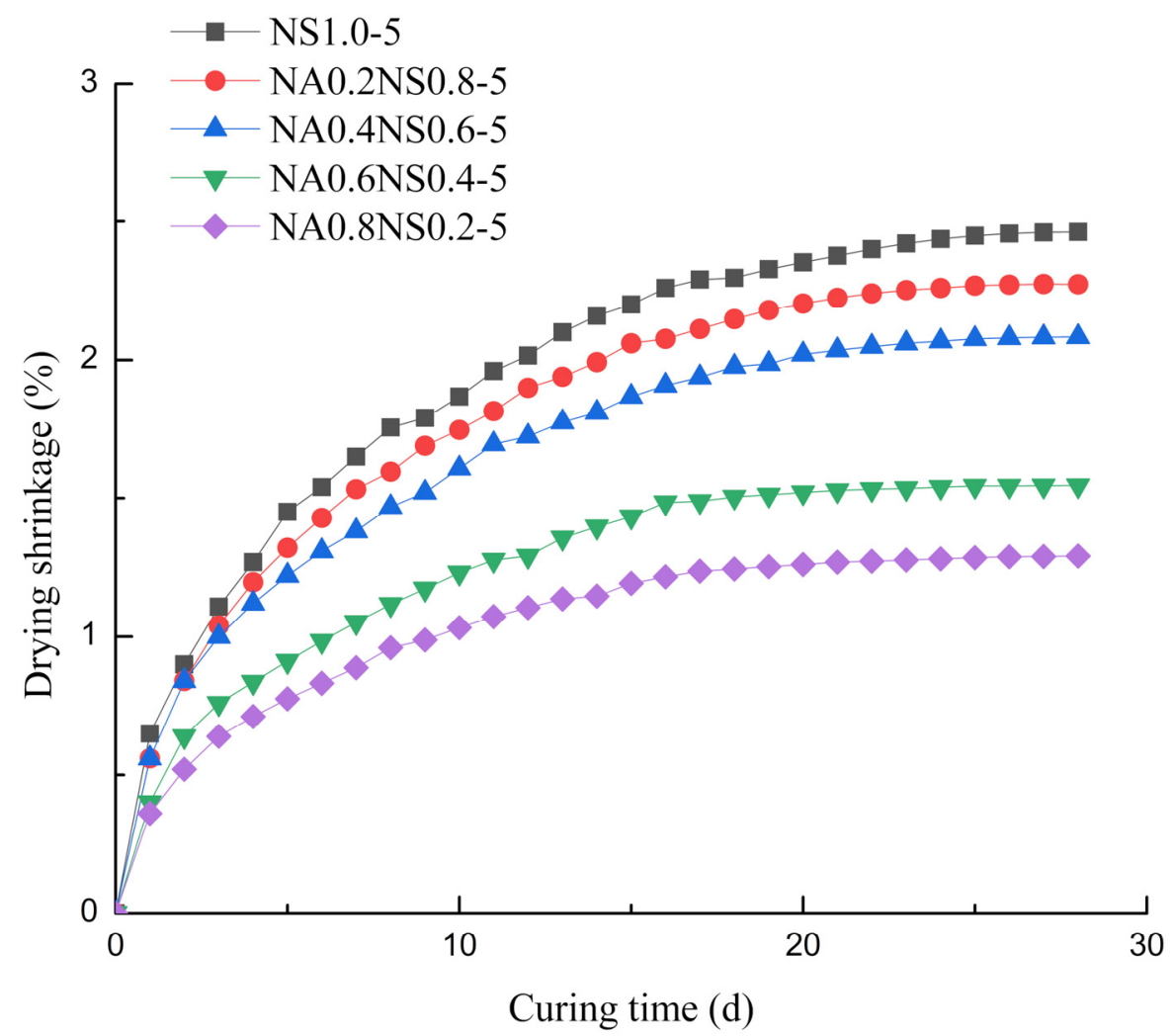

Figure 1. Effect of different $\mathrm{NaAlO}_{2}$ substitution rates on drying shrinkage.

Figure 2 shows the effects of different $\mathrm{Na}_{2} \mathrm{O}$ contents on drying shrinkage at fixed $20 \% \mathrm{NaAlO}_{2}$ substitution rate. The drying shrinkage was also obvious during the first $7 \mathrm{~d}$. At $7 \mathrm{~d}, \mathrm{Na}_{2} \mathrm{O}$ content of $5 \%, 7 \%, 9 \%$ and $11 \%$, the drying shrinkage was $83 \%, 73 \%, 56 \%$ and $30 \%$ of $\mathrm{Na}_{2} \mathrm{O}$ content of $3 \%$, respectively. The $\mathrm{Na}_{2} \mathrm{O}$ content had a clear effect on drying shrinkage: a high $\mathrm{Na}_{2} \mathrm{O}$ content led to low drying shrinkage. As result of low $\mathrm{Na}_{2} \mathrm{O}$ content with low $\mathrm{OH}^{-}$ions concentration, the paste could not complete hydration reaction and residual moisture evaporation led to high drying shrinkage [24]. 
Meng Wu et al. [25] also suggested that amorphous gels lost moisture caused greater drying shrinkage. In general, the mechanism of AAS drying shrinkage was complicated and depended on different $\mathrm{NaAlO}_{2}$ substitution rates and $\mathrm{Na}_{2} \mathrm{O}$ contents.

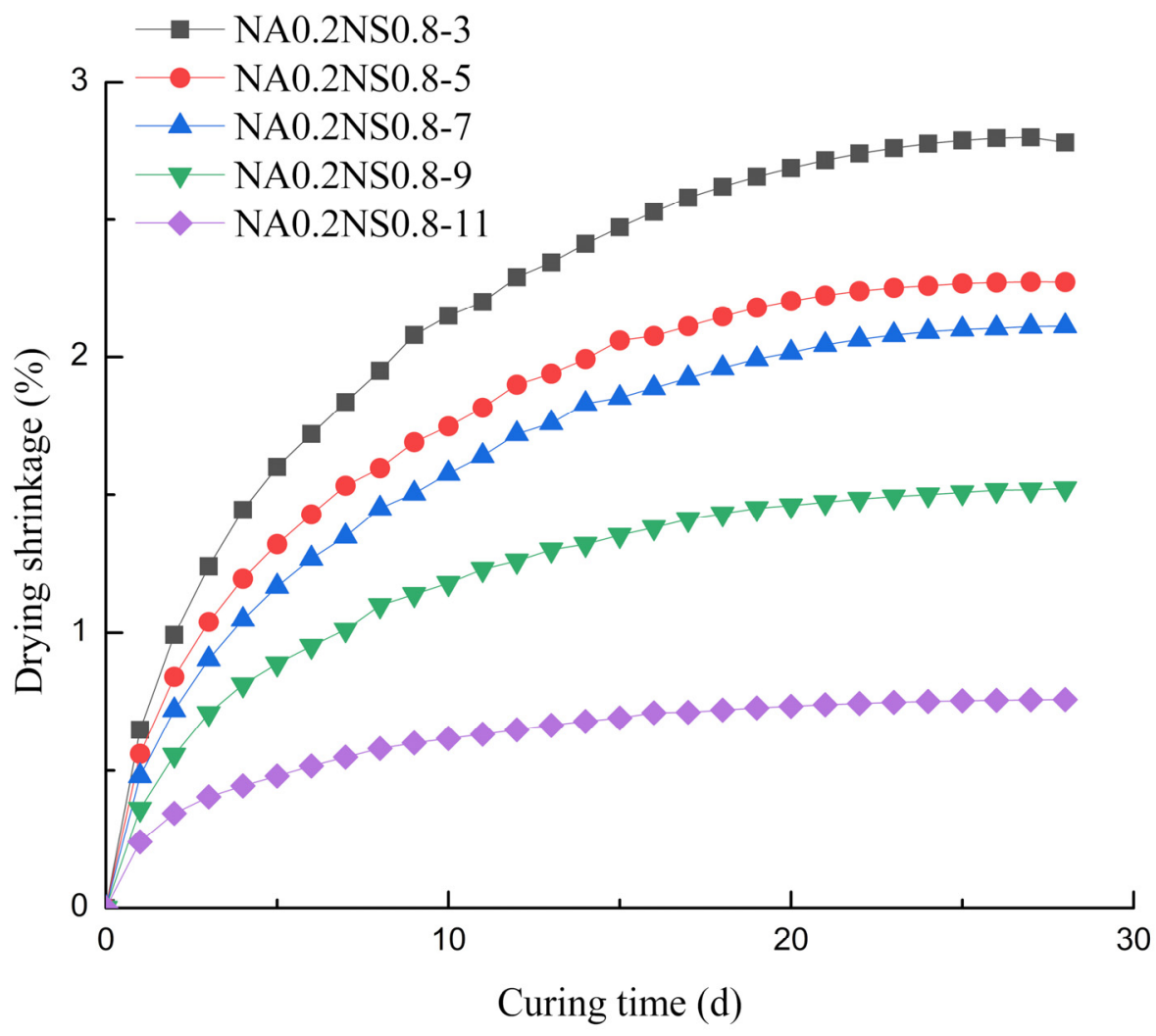

Figure 2. Effect of different $\mathrm{Na}_{2} \mathrm{O}$ contents on drying shrinkage.

\subsection{Autogenous Shrinkage}

Figure 3 shows the effects of different $\mathrm{NaAlO}_{2}$ substitution rates on autogenous shrinkage. Used bellows to test autogenous shrinkage could effectively prevent the loss of water and minimize the constraints on volume changes. Autogenous shrinkage had similar characteristics to drying shrinkage and great influence to mitigate autogenous shrinkage by the $\mathrm{NaAlO}_{2}$ substitution rate increased and also was obvious shrank during the first $7 \mathrm{~d}$. Moreover, the autogenous shrinkage of alkali-activated slag used alkaline activator with $\mathrm{Na}_{2} \mathrm{SiO}_{3}$ alone was still very large, same to findings from by Kumarappa et al. [26]. The sample with substitution rate at $80 \%$, the drying shrinkage at $7 \mathrm{~d}$ and $28 \mathrm{~d}$ were $73 \%$ and $72 \%$ of the control group (NS 1.0-5), respectively.

Figure 4 plots the effects of different $\mathrm{Na}_{2} \mathrm{O}$ contents on autogenous shrinkage at fixed $20 \% \mathrm{NaAlO}_{2}$ substitution rates. By elevating the $\mathrm{Na}_{2} \mathrm{O}$ content, the autogenous shrinkage increased, consistent with the Ma et al. [27] found. However, the results were contrary to the drying shrinkage test results. The autogenous shrinkage happened without the exchange of external substances and the water from paste was not migrated. Hence, high $\mathrm{Na}_{2} \mathrm{O}$ content promoted completed the hydration reaction of the paste, which in turn caused greater autogenous shrinkage [28]. The maximum autogenous shrinkage group (NA0.2NS0.8-11) was 1.4 times and 1.5 times that of the minimum autogenous shrinkage group (NA0.2NS0.8-3) at $7 \mathrm{~d}$ and $28 \mathrm{~d}$, respectively. Then, the phenomenon of autogenous shrinkage with different $\mathrm{Na}_{2} \mathrm{O}$ contents would be consistent with the degree of hydration reaction. Neto et al. [23] also believed that drying shrinkage due to the water evaporation from the paste was more significant than autogenous shrinking. 


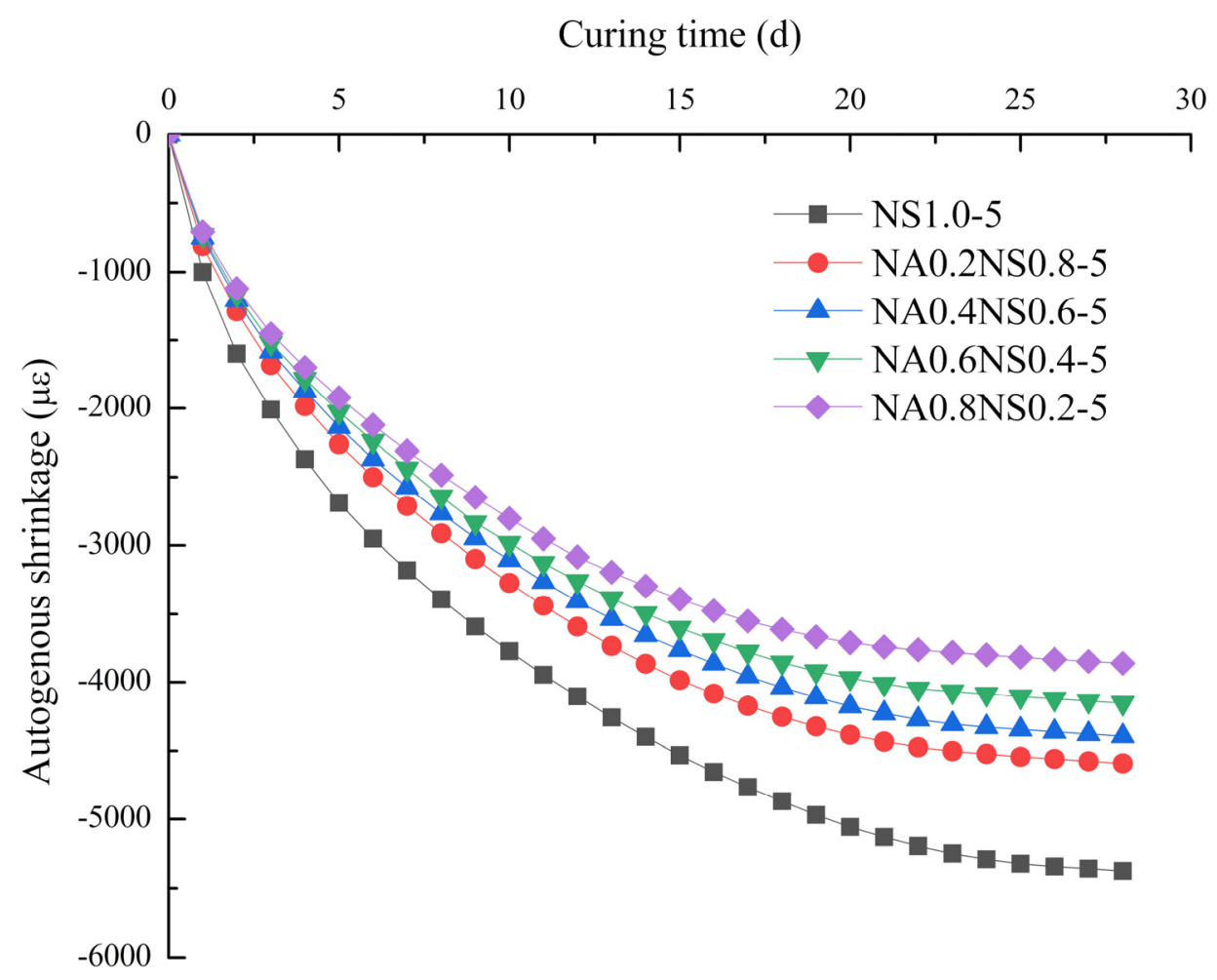

Figure 3. Effect of different $\mathrm{NaAlO}_{2}$ substitution rates on autogenous shrinkage.

Curing time (d)

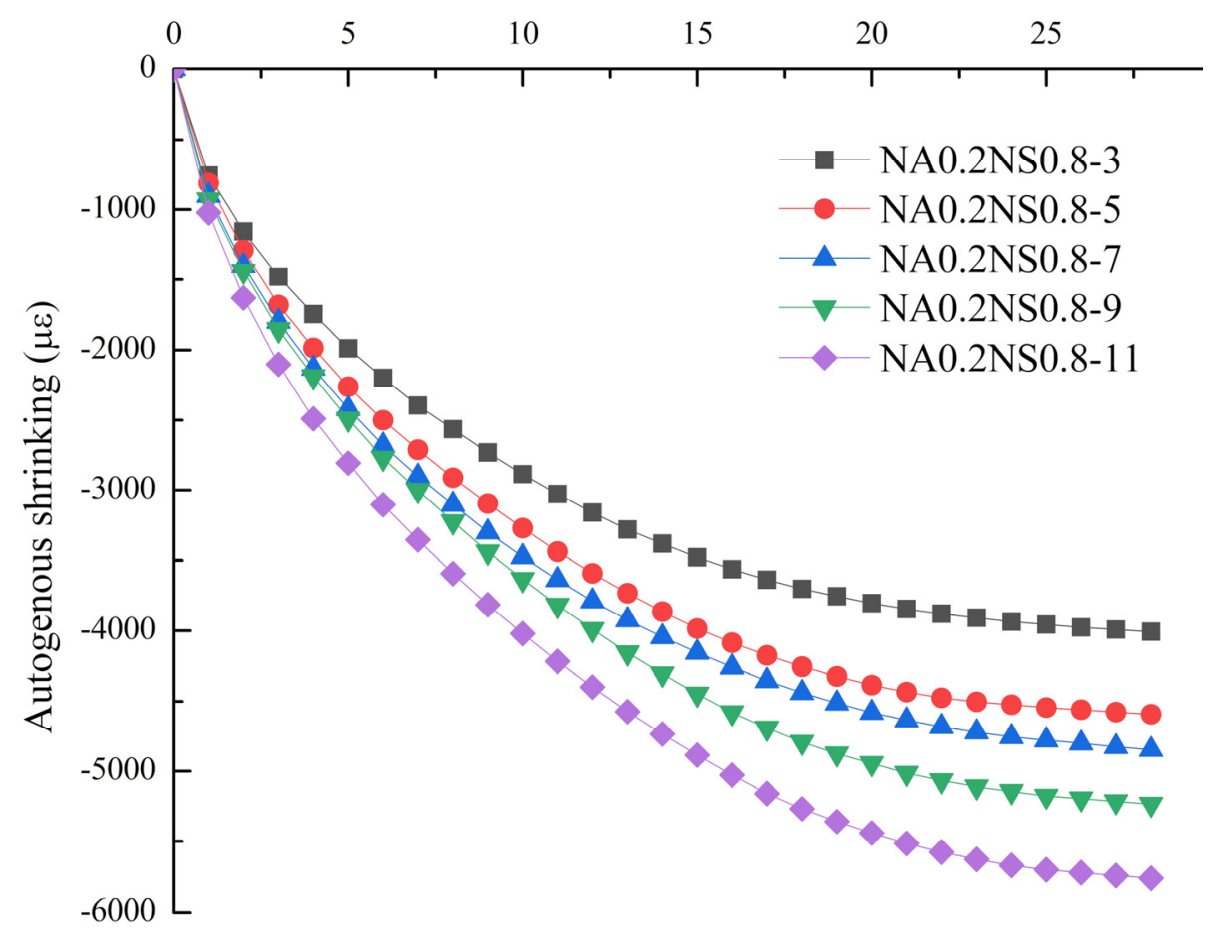

Figure 4. Effect of different $\mathrm{Na}_{2} \mathrm{O}$ contents on autogenous shrinkage.

\section{3. $X R D$}

The composition of the hydration products was analyzed by XRD. The generation of different hydration products had significant impacts on the pore structure and shrinkage properties. By checking 
the results of drying shrinkage and autogenous shrinkage, we found that drying shrinkage and autogenous shrinkage before $7 \mathrm{~d}$ were more severe than that of after $7 \mathrm{~d}$. Therefore, the characteristics of hydration products at $7 \mathrm{~d}$ could explain the different shrinkage changes. Figure 5 shows the XRD image of raw slag and different $\mathrm{NaAlO}_{2}$ substitution rates at $7 \mathrm{~d}$. The characteristic phenomenon at approximately $30^{\circ}$ of all AAS was a feature corresponding to big quantity of amorphous products which were C-(A)-S-H gels [29]. Calcite was found in all pastes and was generated by sample carbonization during preparation and curing time [30]. However, hydrotalcite and tetranatrolite were also major products found in this research. Hydrotalcite had micro-expansion in a certain degree; tetranatrolite was a zeolite phase structure, which was beneficial to mitigate paste shrinkage [31]. At the same time, as the substitution rate of $\mathrm{NaAlO}_{2}$ increased, the amount of hydrotalcite and tetranatrolite also increased, which generated different shrinkage mitigation effects among all the AAS—and was consistent with the results of the drying shrinkage test.

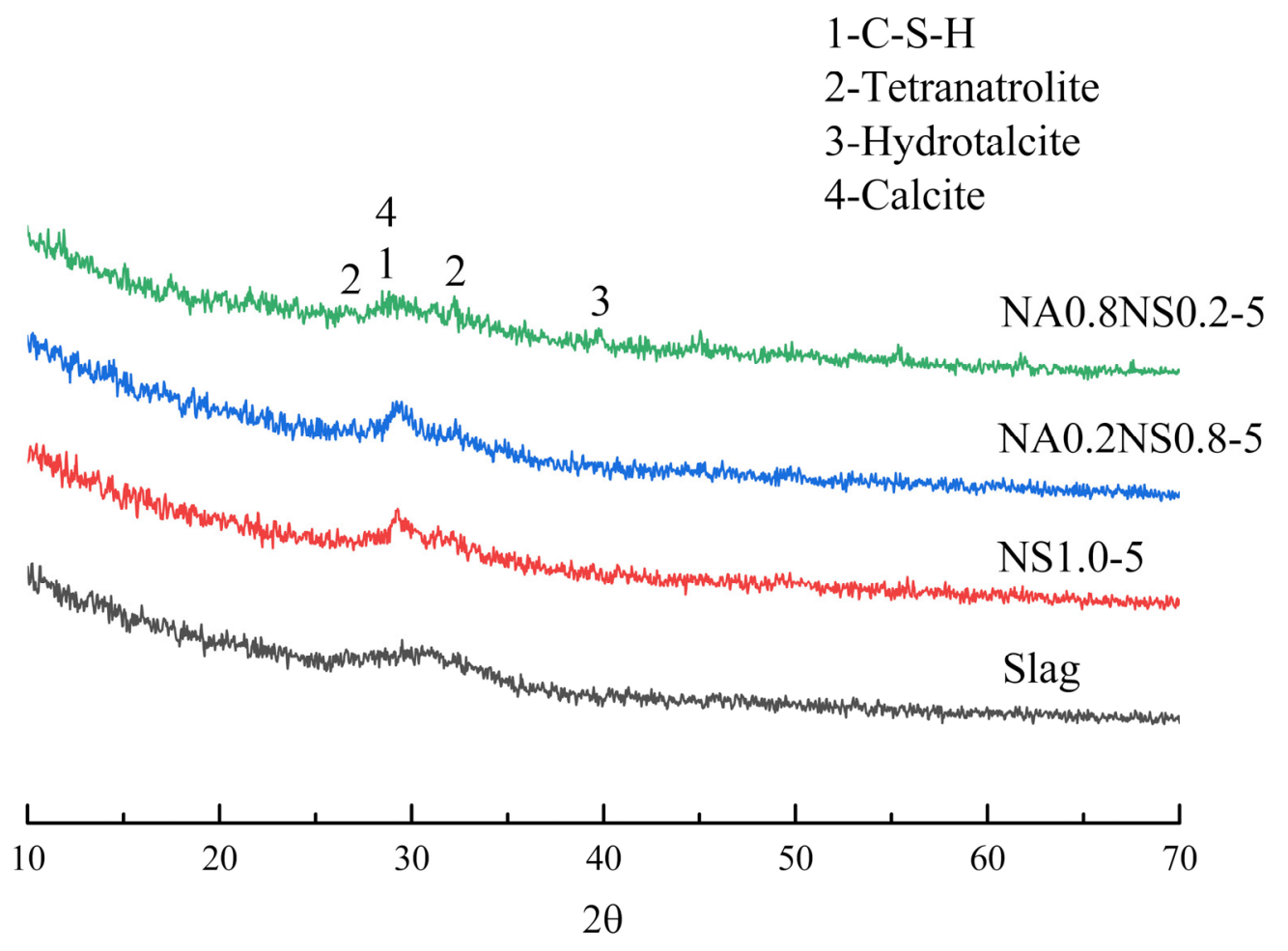

Figure 5. XRD image of raw slag and different $\mathrm{NaAlO}_{2}$ substitution rates at $7 \mathrm{~d}$.

\subsection{SEM}

The microscopic structure of AAS with different $\mathrm{NaAlO}_{2}$ substitution rates at $7 \mathrm{~d}$ and $28 \mathrm{~d}$ were analyzed by SEM. The progress of hydration reaction was investigated by studying the microscopic morphology. The density of hydration products and the changes of voids could be retrieved directly from the SEM, which contributed to better understanding of the mechanism of hydration. Figure 6 shows the microscopic structure of AAS with the different $\mathrm{NaAlO}_{2}$ substitution rates at $7 \mathrm{~d}$ and $28 \mathrm{~d}$. The specimen NS1.0-5 was significantly denser than that of NA0.2NS0.8-5 and NA0.8NS0.2-5. The slag was almost completely dissolved and generated more $\mathrm{C}-\mathrm{A}-\mathrm{S}-\mathrm{H}$ gels and less voids at $7 \mathrm{~d}$. $\mathrm{The}_{2} \mathrm{Na}_{2} \mathrm{SiO}_{3}$ was conducive to the progress of the hydration reaction and could make the hydration reaction more complete. This showed that $\mathrm{NaAlO}_{2}$ partially substituted $\mathrm{Na}_{2} \mathrm{SiO}_{3}$ as a composite alkaline activator, inhibiting the progress of hydration reaction, delaying and reducing the formation of hydration products of AAS, which supports the conclusions of Ben et al. [31].

The phenomenon of microstructure at $28 \mathrm{~d}$ was exactly opposite of that at $7 \mathrm{~d}$. The specimen NA0.8NS0.2-5 generated denser structure (for mainly C-A-S-H gels) at $28 \mathrm{~d}$, and the microstructure 
was denser than that of NS1.0-5. This indicates that NA0.8NS0.2-5 had a more complete hydration reaction at $28 \mathrm{~d}$. Moreover, the $\mathrm{NaAlO}_{2}$ substitution rates difference had significant impact on the formation of $28 \mathrm{~d}$ hydration products. This may be due to the addition of $\mathrm{NaAlO}_{2}$ having an inhibitory effect on the hydration reaction in the early phase, but a motivating effect on the reaction in the later phase, which supports the research of Huang et al. [32]. The NA0.8NS0.2-5 clearly had completed hydration reaction to generate more gels where micropores mainly existed. Compared with other samples, NA0.8NS0.2-5 had the most amount of gels, which meant a higher micropore-to-volume ratio was excited, which corresponded to the BET results.
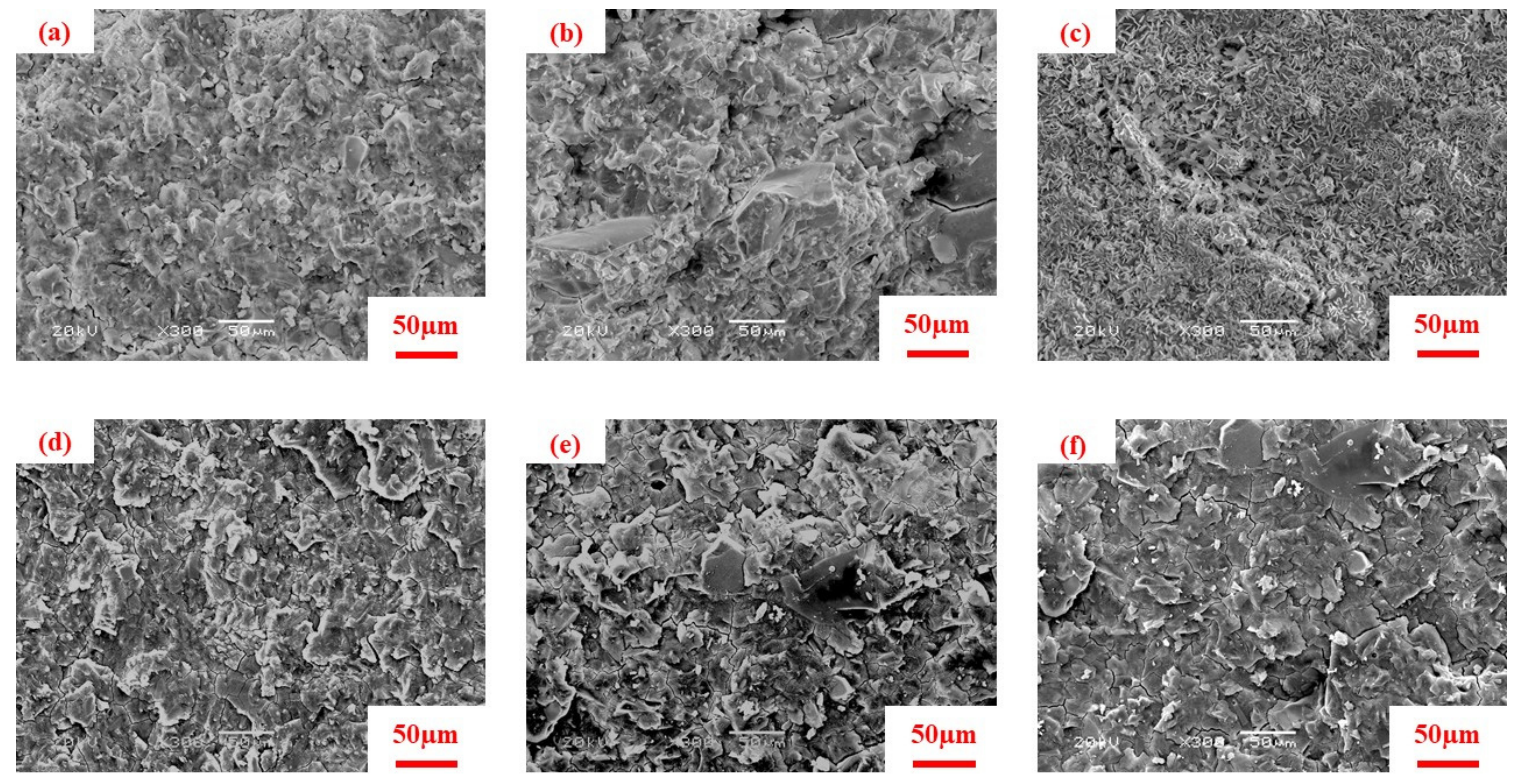

Figure 6. Microscopic structure of AAS with different $\mathrm{NaAlO}_{2}$ substitution rates at $7 \mathrm{~d}$ and $28 \mathrm{~d}$. (a) NS1.0-5 at $7 \mathrm{~d}$; (b) NA0.2NS0.8-5 at $7 \mathrm{~d}$; (c) NA0.8NS0.2-5 at $7 \mathrm{~d} ;$ (d) NS1.0-5 at $28 \mathrm{~d}$; (e) NA0.2-NS0.8-5 at $28 \mathrm{~d} ;$ (f) NA0.8NS0.2-5 at $28 \mathrm{~d}$.

\subsection{BET}

Many studies found that the volume proportions of pore structure have critical impact on the shrinkage properties of AAS $[33,34]$. The pore size was determined to measure by the Brunauer-Emmett-Teller (BET) theory. The specimens at $28 \mathrm{~d}$ were tested to observe the volume proportion of AAS pore structure. The pore sizes were in the range of $1.7-300 \mathrm{~nm}$. According to Zhongwei $\mathrm{Wu}$, a Chinese academic, the pore structure of cement-based materials be classified as micropores $(\mathrm{d}<20 \mathrm{~nm})$, mesopores $(20 \mathrm{~nm}<\mathrm{d}<50 \mathrm{~nm})$ and macropores $(\mathrm{d}>50 \mathrm{~nm})$. The volume proportions of pore structure distribution of AAS showed in Table 3.

Table 3. Volume proportions of pore structure distribution of AAS.

\begin{tabular}{ccccc}
\hline \multirow{2}{*}{ Code } & \multirow{2}{*}{ Total Porosity (\%) } & \multicolumn{3}{c}{ Volume Proportions (\%) } \\
\cline { 3 - 5 } & & Micropores & Mesopores & Macropores \\
\hline NS1.0-5 & 6.94 & 32.06 & 30.36 & 37.58 \\
NA0.2 NS0.8-5 & 3.90 & 60.89 & 23.20 & 15.91 \\
NA0.8 NS0.2-5 & 3.53 & 61.67 & 26.27 & 12.06 \\
NA0.2 NS0.8-3 & 13.41 & 75.92 & 8.45 & 15.63 \\
NA0.2 NS0.8-7 & 2.12 & 34.39 & 33.63 & 31.98 \\
NA0.2 NS0.8-11 & 1.07 & 16.24 & 30.14 & 53.62 \\
\hline
\end{tabular}


The pore-size distributions of AAS with different $\mathrm{NaAlO}_{2}$ substitution rates are shown in Figure 7, mainly concentrated between 1.7-20 nm. Based on Figure 7, a higher $\mathrm{NaAlO}_{2}$ substitution rate resulted to lower total proportion of porosity and higher micropores volume. The reduction of total porosity was beneficial to mitigate drying shrinkage. When the $\mathrm{NaAlO}_{2}$ substitution rates were $20 \%$ and $80 \%$, the total porosities were $56 \%$ and $51 \%$ of the control group (NS1.0-5), respectively, which was consistent with the drying shrinkage and SEM results. On the other hand, the adjustment in pore-size distribution also had significant effects on the drying shrinkage. The substitution rate increased with higher micropores volume proportion, which was the reason the drying shrinkage reduced. The highest substitution rate corresponded to the largest micropores volume proportion of $61.67 \%$, which also corresponded with the smallest drying shrinkage. This indicates that the micropore volume proportion had a significant effect on drying shrinkage. Compare this to the discussion by Chen et al. [35], namely, that that pore structure also has significant effect on drying shrinkage: a higher micropore volume proportion can result in a greater drying shrinkage, which was contrary to the phenomenon found in this study. The reason for the difference in Chen's conclusion was that the hydration products had no changes. However, in this study, the addition of $\mathrm{NaAlO}_{2}$ changed the hydration products. Based on the findings from the XRD results, more hydrotalcite and tetranatrolite were generated. Nevertheless, the micropores only existed in the gels, so the micropores volume proportion increased may correspond to the increased in the amount of hydrotalcite and tetranatrolite [36]. As discussed in this article, both hydrotalcite and tetranatrolite contributed to mitigate drying shrinkage and generated lower drying shrinkage with more micropores volume proportion.

(a)

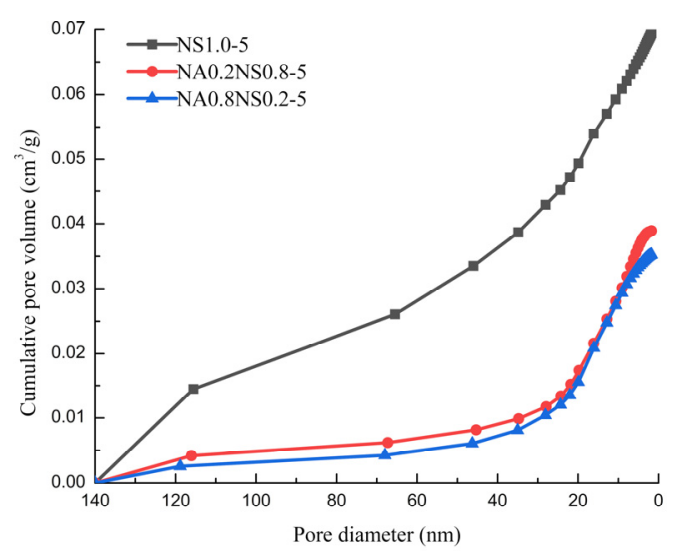

(c) (b)

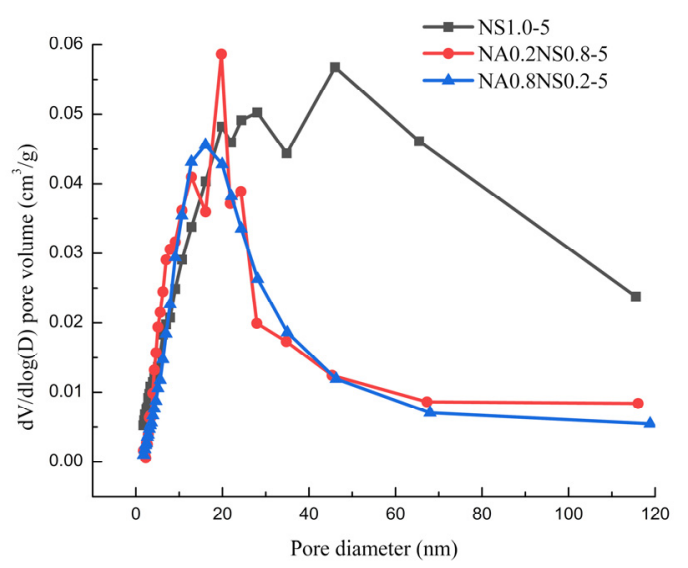

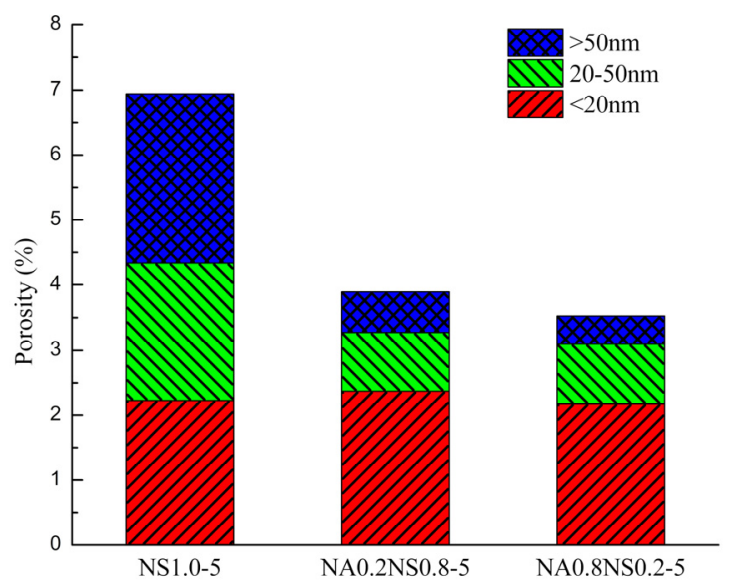

Figure 7. Pore-size distribution of AAS with different $\mathrm{NaAlO}_{2}$ substitution rates. (a) Cumulative intrusion; (b) different intrusion; (c) porosity. 
The critical pore size was determined by examining the differential pore volume curves. The pore-size distribution of the code of NS1.0-5 and NA0.2NS0.8-5 were multimodal pore distributions, but the code of NA0.8NS0.2-5 was observed to have a unimodal pore distribution. The critical pore diameter of control group (NS1.0-5) was $46 \mathrm{~nm}$; the critical pore diameter of NA0.2NS0.8-5 and NA0.8NS0.2-5 was reduced to $20 \mathrm{~nm}$ and $16 \mathrm{~nm}$, respectively. As the substitution rate of $\mathrm{NaAlO}_{2}$ increased, the value of the critical pore diameter decreased, which led to less shrinkage. Kumarappa [26] had a same conclusion. In addition, the order of critical pore size had a similar trend to the total porosity (NS1.0-5 > NA0.2NS0.8-5 > NA0.8NS0.2-5).

The pore-size distributions of AAS with different $\mathrm{Na}_{2} \mathrm{O}$ contents are shown in Figure 8. $\mathrm{As} \mathrm{Na}_{2} \mathrm{O}$ content increased, the total porosity and micropores volume proportion decreased. The content of $\mathrm{Na}_{2} \mathrm{O}$ content increased from 3 to $11 \%$. The micropore volume proportions decreased from $75.92 \%$ to $16.24 \%$. A higher $\mathrm{Na}_{2} \mathrm{O}$ content led to more complete reaction, and the paste became denser and the total porosity decreased, which supports the research of Chindaprasirt et al. [37]. At this point, the largest micropores volume proportion corresponded to the maximum drying shrinkage- - the same as concluded by Yang et al. [38]. The micropores of diameter $1.25-25 \mathrm{~nm}$ were the main reason for AAS drying shrinkage. However, contrary to the conclusions obtained by the different substitution rates above, the major reason was that the $\mathrm{NaAlO}_{2}$ substitution rate was fixed and changed the $\mathrm{Na}_{2} \mathrm{O}$ content could not change the composition of the generated phase. More micropore volume proportions in the same generated paste led to greater drying shrinkage.

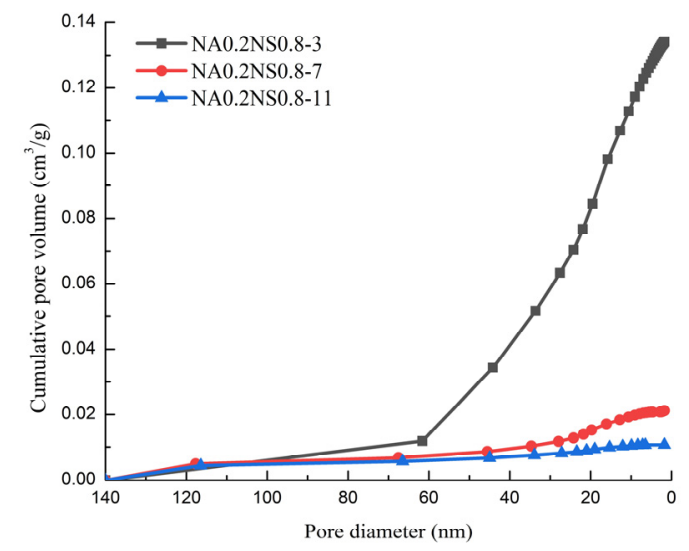

(c) (b)

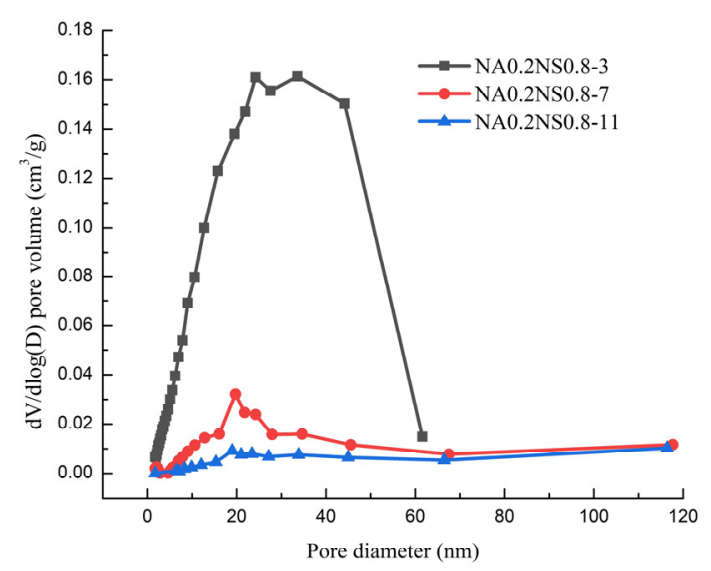

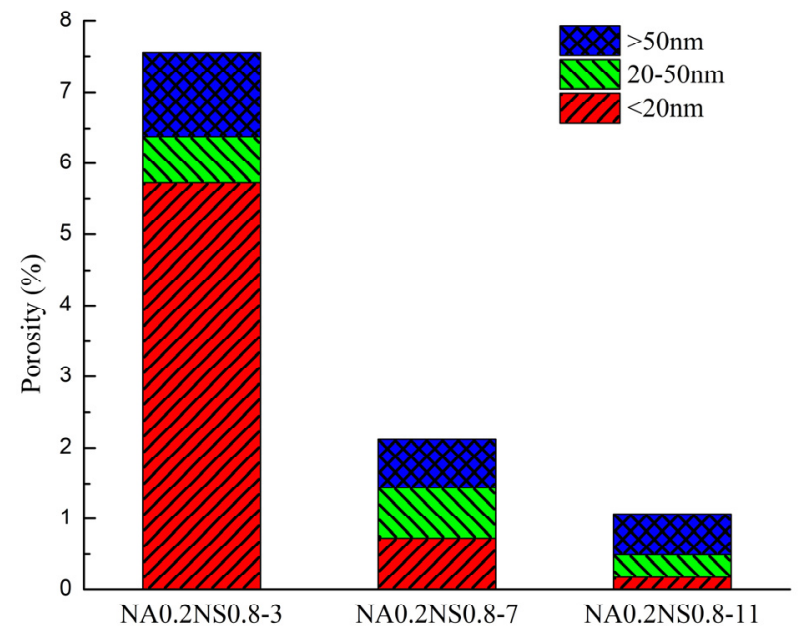

Figure 8. Pore-size distribution of AAS with different $\mathrm{Na}_{2} \mathrm{O}$ contents. (a) Cumulative intrusion; (b) different intrusion; (c) porosity. 
Furthermore, as the $\mathrm{Na}_{2} \mathrm{O}$ content elevated, the critical pore size became smaller, which corresponded to the lower shrinkage and was consistent with the results of the different $\mathrm{NaAlO}_{2}$ substitution rates.

\section{Conclusions}

In this study, the mitigation function of alkali-activated slag-drying shrinkage and autogenous shrinkage mixed with $\mathrm{NaAlO}_{2}$ was studied. The mechanism and reason of mitigating shrinkage were discussed. According to the research in this article, the conclusions are as follows:

1. Through $\mathrm{NaAlO}_{2}$ addition, the drying shrinkage and autogenous shrinkage could be clearly mitigated. In addition, the solid alkaline activator provided a convenient way of preparation and curing and reduced damage from alkaline corrosion;

2. The addition of $\mathrm{NaAlO}_{2}$ slowed the early hydration reaction, while made the later hydration reaction more complete, reducing the total porosity, changing the pore-size distribution and having a significant impact on the shrinkage performance;

3. Added $\mathrm{NaAlO}_{2}$ could generate hydrotalcite and tetranatrolite, and the generation increased with increased added $\mathrm{NaAlO}_{2}$. Moreover, the change of the generated phase composition clearly mitigated shrinkage of AAS;

4. For $\mathrm{AAS}$ with different $\mathrm{Na}_{2} \mathrm{O}$ contents, the evaporation from the paste played a major role in drying shrinkage and the degree of hydration reaction mainly contributed to autogenous shrinkage.

Author Contributions: Conceptualization, B.C., J.W.; methodology, B.C.; validation, B.C., J.W.; formal analysis, B.C., J.W.; investigation, J.Z.; resources, J.W.; data curation, B.C., J.W.; writing-original draft preparation, B.C.; writing-review and editing, B.C., J.W.; visualization, J.W., J.Z.; supervision, B.C., J.W.; project administration, B.C., J.W.; funding acquisition, J.W. All authors have read and agreed to the published version of the manuscript.

Funding: This research was funded by Heilongjiang Traffic and Transportation Department, Grant Number JTZD-20181826.

Conflicts of Interest: The authors declare no conflicts of interest.

\section{References}

1. Mobili, A.; Belli, A.; Giosuè, C.; Bellezze, T.; Tittarelli, F. Metakaolin and fly ash alkali-activated mortars compared with cementitious mortars at the same strength class. Cem. Concr. Res. 2016, 88, 198-210. [CrossRef]

2. McLellan, B.C.; Williams, R.P.; Lay, J.; van Riessen, A.; Corder, G.D. Costs and carbon emissions for geopolymer pastes in comparison to ordinary portland cement. J. Clean. Prod. 2011, 19, 1080-1090. [CrossRef]

3. Yang, K.-H.; Song, J.-K.; Song, K.-I. Assessment of CO2 reduction of alkali-activated concrete. J. Clean. Prod. 2013, 39, 265-272. [CrossRef]

4. Provis, J.L.; Palomo, A.; Shi, C. Advances in understanding alkali-activated materials. Cem. Concr. Res. 2015, 78, 110-125. [CrossRef]

5. Li, C.; Sun, H.; Li, L. A review: The comparison between alkali-activated slag ( $\mathrm{Si}+\mathrm{Ca})$ and metakaolin $(\mathrm{Si}+\mathrm{Al})$ cements. Cem. Concr. Res. 2010, 40, 1341-1349. [CrossRef]

6. Jang, J.G.; Lee, N.K.; Lee, H.K. Fresh and hardened properties of alkali-activated fly ash/slag pastes with superplasticizers. Constr. Build. Mater. 2014, 50, 169-176. [CrossRef]

7. Collins, F.; Sanjayan, J.G. Strength and shrinkage properties of alkali-activated slag concrete placed into a large column. Cem. Concr. Res. 1999, 29, 659-666. [CrossRef]

8. Lee, N.K.; Jang, J.G.; Lee, H.K. Shrinkage characteristics of alkali-activated fly ash/slag paste and mortar at early ages. Cem. Concr. Compos. 2014, 53, 239-248. [CrossRef]

9. Duran Atiş, C.; Bilim, C.; Çelik, Ö.; Karahan, O. Influence of activator on the strength and drying shrinkage of alkali-activated slag mortar. Constr. Build. Mater. 2009, 23, 548-555. [CrossRef]

10. Cartwright, C.; Rajabipour, F.; Radliska, A. Shrinkage characteristics of alkali-activated slag cements. J. Mater. Civ. Eng. 2015, 27, B4014007. [CrossRef]

11. Hojati, M.; Radlińska, A. Shrinkage and strength development of alkali-activated fly ash-slag binary cements. Constr. Build. Mater. 2017, 150, 808-816. [CrossRef] 
12. Ye, H.; Radlińska, A. Shrinkage mitigation strategies in alkali-activated slag. Cem. Concr. Res. 2017, 101, 131-143. [CrossRef]

13. Kalina, L.; Bílek, V.; Bartoníčková, E.; Kalina, M.; Hajzler, J.; Novotný, R. Doubts over capillary pressure theory in context with drying and autogenous shrinkage of alkali-activated materials. Constr. Build. Mater. 2020, 248, 118620. [CrossRef]

14. Coppola, L.; Coffetti, D.; Crotti, E.; Candamano, S.; Crea, F.; Gazzaniga, G.; Pastore, T. The combined use of admixtures for shrinkage reduction in one-part alkali activated slag-based mortars and pastes. Constr. Build. Mater. 2020, 248, 118682. [CrossRef]

15. Song, C.; Choi, Y.C.; Choi, S. Effect of internal curing by superabsorbent polymers-Internal relative humidity and autogenous shrinkage of alkali-activated slag mortars. Constr. Build. Mater. 2016, 123, 198-206. [CrossRef]

16. Abdel-Gawwad, H.A.; Mohammed, M.S.; Alomayri, T. Single and dual effects of magnesia and alumina nano-particles on strength and drying shrinkage of alkali activated slag. Constr. Build. Mater. 2019, 228, 116827. [CrossRef]

17. Ben, H.M.; Lothenbach, B.; Le Saout, G.; Winnefeld, F. Influence of slag chemistry on the hydration of alkali-activated blast-furnace slag-Part II: Effect of $\mathrm{Al}_{2} \mathrm{O}_{3}$. Cem. Concr. Res. 2012, 42, 74-83. [CrossRef]

18. Sakulich, A.R.; Anderson, E.; Schauer, C.L.; Barsoum, M.W. Influence of Si:Al ratio on the microstructural and mechanical properties of a fine-limestone aggregate alkali-activated slag concrete. Mater. Struct. 2010, 43, 1025-1035. [CrossRef]

19. Standardization Administration of the People's Republic of China. GB/T 18046-2017: Ground Granulated Blast Furnace Slag Uesd for Cement, Mortar and Concrete; China Standards Press: Beijing, China, 2017; p. 2.

20. Ministry of Housing and Urban-Rural Development of People's Repoblic of China. GB/T 50081-2019: Standard for Test Methods of Concrete Physical and Mechanical Properties; China Buliding Materials Industry Press: Beijing, China, 2019; pp. 12-14.

21. ASTM C1698-09 Standard Test Method for Autogenous Strain of Cenment Paste and Mortar; ASTM Inernational: West Conshohocken, PA, USA, 2009.

22. Ye, H.; Cartwright, C.; Rajabipour, F.; Radliska, A. Understanding the drying shrinkage performance of alkali-activated slag mortars. Cem. Concr. Compos. 2017, 76, 13-24. [CrossRef]

23. Melo Neto, A.A.; Cincotto, M.A.; Repette, W. Drying and autogenous shrinkage of pastes and mortars with activated slag cement. Cem. Concr. Res. 2008, 38, 565-574. [CrossRef]

24. Qureshi, M.N.; Ghosh, S. Effect of Silicate Content on the Properties of Alkali-Activated Blast Furnace Slag Paste. Arab. J. Sci. Eng. 2014, 39, 5905-5916. [CrossRef]

25. Wu, M.; Zhang, Y.; Jia, Y.; She, W.; Liu, G. Study on the role of activators to the autogenous and drying shrinkage of lime-based low carbon cementitious materials. J. Clean. Prod. 2020, 257, 120522. [CrossRef]

26. Ballekere Kumarappa, D.; Peethamparan, S.; Ngami, M. Autogenous shrinkage of alkali activated slag mortars: Basic mechanisms and mitigation methods. Cem. Concr. Res. 2018, 109, 1-9. [CrossRef]

27. Ma, Y.; Ye, G. The shrinkage of alkali activated fly ash. Cem. Concr. Res. 2015, 68, 75-82. [CrossRef]

28. Li, Z.; Lu, T.; Liang, X.; Dong, H.; Ye, G. Mechanisms of autogenous shrinkage of alkali-activated slag and fly ash pastes. Cem. Concr. Res. 2020, 135, 106107. [CrossRef]

29. Bernal, S.A.; Provis, J.L.; Brice, D.G.; Kilcullen, A.; Duxson, P.; Van Deventer, J.S.J. Accelerated carbonation testing of alkali-activated binders significantly underestimates service life: The role of pore solution chemistry. Cem. Concr. Res. 2012, 42, 1317-1326. [CrossRef]

30. Rashad, A.M.; Zeedan, S.R.; Hassan, A.A. Influence of the activator concentration of sodium silicate on the thermal properties of alkali-activated slag pastes. Constr. Build. Mater. 2016, 102, 811-820. [CrossRef]

31. Haha, M.B.; Lothenbach, B.; Le Saout, G.; Winnefeld, F. Influence of slag chemistry on the hydration of alkali-activated blast-furnace slag-Part I: Effect of MgO. Cem. Concr. Res. 2011, 41, 955-963. [CrossRef]

32. Huang, Y.; Han, M. The influence of $\alpha-\mathrm{Al} 2 \mathrm{O} 3$ addition on microstructure, mechanical and formaldehyde adsorption properties of fly ash-based geopolymer products. J. Hazard. Mater. 2011, 193, 90-94. [CrossRef]

33. Mastali, M.; Kinnunen, P.; Dalvand, A.; Mohammadi Firouz, R.; Illikainen, M. Drying shrinkage in alkali-activated binders A critical review. Constr. Build. Mater. 2018, 190, 533-550. [CrossRef]

34. You, N.; Liu, Y.; Gu, D.; Ozbakkaloglu, T.; Pan, J.; Zhang, Y. Rheology, shrinkage and pore structure of alkali-activated slag-fly ash mortar incorporating copper slag as fine aggregate. Constr. Build. Mater. 2020, 242, 118029. [CrossRef] 
35. Chen, H.; Wyrzykowski, M.; Scrivener, K.; Lura, P. Prediction of self-desiccation in low water-to-cement ratio pastes based on pore structure evolution. Cem. Concr. Res. 2013, 49, 38-47. [CrossRef]

36. Khalid, H.R.; Lee, N.K.; Park, S.M.; Abbas, N.; Lee, H.K. Synthesis of geopolymer-supported zeolites via robust one-step method and their adsorption potential. J. Hazard. Mater. 2018, 353, 522-533. [CrossRef] [PubMed]

37. Chindaprasirt, P.; Chareerat, T.; Hatanaka, S.; Cao, T. High-Strength Geopolymer Using Fine High-Calcium Fly Ash. J. Mater. Civ. Eng. 2011, 23, 264-270. [CrossRef]

38. Yang, J.; Wang, Q.; Zhou, Y. Influence of Curing Time on the Drying Shrinkage of Concretes with Different Binders and Water-to-Binder Ratios. Adv. Mater. Sci. Eng. 2017, 2017. [CrossRef]

(C) 2020 by the authors. Licensee MDPI, Basel, Switzerland. This article is an open access article distributed under the terms and conditions of the Creative Commons Attribution (CC BY) license (http://creativecommons.org/licenses/by/4.0/). 